\title{
Development of the Czech Farmers' Age Structure and the Consequences for Subsidy Policy
}

\author{
O. Šimpach 1 , M. Pechrová ${ }^{2}$ \\ ${ }^{1}$ Faculty of Informatics and Statistics, University of Economics Prague, Czech Republic \\ ${ }^{2}$ Faculty of Economics and Management, Czech University of Life Sciences Prague, Czech Republic
}

\begin{abstract}
Anotace
Jedině na základě znalosti vývoje věkové struktury zemědělských pracovníků v budoucnu je možné formulovat kroky k jejímu zlepšení a plánovat financování opatření pro podporu mladých zemědělců. Cílem článku je s ohledem na programová období Evropské unie projektovat věkové a pohlavní struktury zemědělských pracovníků do roku 2041 a modelovat možné scénáře vývoje dotačních podpor. Pro projekci dvou variant populačního vývoje je použita kohortně-komponentní metoda a data ze Sčítání lidu, domů a bytů v roce 2011 .

Počet zemědělců nad 55 let překročí počet mladých v roce 2026. Mladých manažerů nebo vlastníků zemědělských podniků bude nejméně v roce 2035. Pak nastane růst, protože do plodivého období vstoupí druhá generace tzv. Husákových dětí. Důsledkem toho bude možné (a i nutné pro zlepšení věkové struktury) podpořit více žadatelů. Zatímco v roce 2011 bylo 205,7 miliardami Kč podpořeno 12,1 \% mladých zemědělců (potenciálních žadatelů o dotaci), v roce 2041 bude stejná částka stačit na 18,6 \%.
\end{abstract}

\section{Klíčová slova}

Dotační politika, mladý zemědělec, populační projekce, věková struktura.

\begin{abstract}
Only knowing the future development of the farmers' age structure, it is possible to formulate the steps for its improvement and to plan young farmers' support. The aim of the paper is (with regard to the European Union's programme periods) to project the age-and-sex structure of agricultural workers until 2041 and to model the scenarios of subsidies supports. Cohort-component method and data from Census 2011 are used for projection of two variants of population development.

The number of old agricultural workers will exceed the number of young in 2026. It will start to grow after as the second generation of children born during the $70 \mathrm{~s}$ of the last century (under the strong pro-population policy of the communist regime and the government of President Gustav Husák) will enter the reproduction period. As an implication it will be possible (and necessary) to support more applicants. While in 2011 it there were 12.1\% of young farmers (potential applicants for subsidies) supported by EUR 205.7 bil., this amount will be able to cover $18.6 \%$ in 2041 .
\end{abstract}

\section{Key words}

Age-and-sex structure, population projection, subsidies' policy, young farmer.

\section{Introduction}

Unfavourable age structure of the agricultural workers is a long discussed problem. It is desirable that the agricultural holdings are managed by young farmers as they "have a longer planning horizon and tend to invest more heavily in business growth than comparable older age groups"
(Davis et al., 2013). Also Galanopoulos et al. (2011) proclaims that , the old age of the farmers and the lack of successors is often the main reason for poor adoption levels of novel production techniques and improved management systems, which in turn, can only be realized under the presence of economies of scale." Davis et al. (2009) supposed that when the age or the size 
of the holding is correlated with the farm performance that the reduction of the number of the old farmers and increasing average size of other farms will have potential benefits for other farms. However, their analysis of company data did not found any statistically significant differences between farmers dependent on the age. According to Davis et al. (2009) simple replacement of old farmers by young ones would not bring any significant improvement of the company's performance.

Also the young farmers may tend to experiment less with alternative land management. For example Alexopoulos et al. (2010) surveyed the conversion to organic farms in Greece and concluded that "older farmers owning larger farms are more likely to have adopted organic farming". Polain et al. (2011) deals with the issue of old farmers in Australia from sociological point of view. Existential questions raised by old farmers are solved qualitatively, not quantitatively. The Australian population as a whole is generally old and the problem of aging is frequently discussed topic in other socio-economic issues. Polain et al. (2011) based their research on the original primary data from a sample survey, Alexopoulos et al. (2010) as well as Zawojska (2011) used data from European institutions. Database for our calculation come from Czech Statistical office (Census 2011) and Ministry of Agriculture.

Despite that the impact of the young farmers' management on the farms' performance is ambiguous there is still a clear need to attract new entrants to the agricultural sector. Therefore, there were several measures set under the Common Agricultural Policy of the European Union (EU) in order to reverse the negative trend of agricultural workers population aging and to promote structural changes. One of the schemes was the support for early retirement of farms' owners over 55 years old and the second one the support of young farmers (less than 40 year old). Both measures were part of the Rural Development Program of the Czech Republic for the years 2007-2013 (RDP), but the first mentioned was not implemented in the end.

For the new programming period 2015-2020 there is a similar measure proposed - operation 6.1.1. - Setting up of young farmers' business. Eligible beneficiary is a starting young farmer under the age of forty who firstly initiating the agricultural activity, have agricultural qualifications (or have the opportunity to obtain it), and run agricultural production for maximum 36 months. He or she will also have to submit a business plan and implement it within nine months after the submission of the grant (Ministry of Agriculture of the Czech Republic - MoA, 2014a).

There were seven calls for submission of the application for a grant $\left(1^{\text {st }}\right.$ round in 2007, $3^{\text {rd }}$ in $2008,6^{\text {th }}$ in $2009,9^{\text {th }}$ in $2010,12^{\text {th }}$ in 2011 and $16^{\text {th }}$ in 2012) announced by the MoA (see Fig. 1). In total, there were 3606 projects

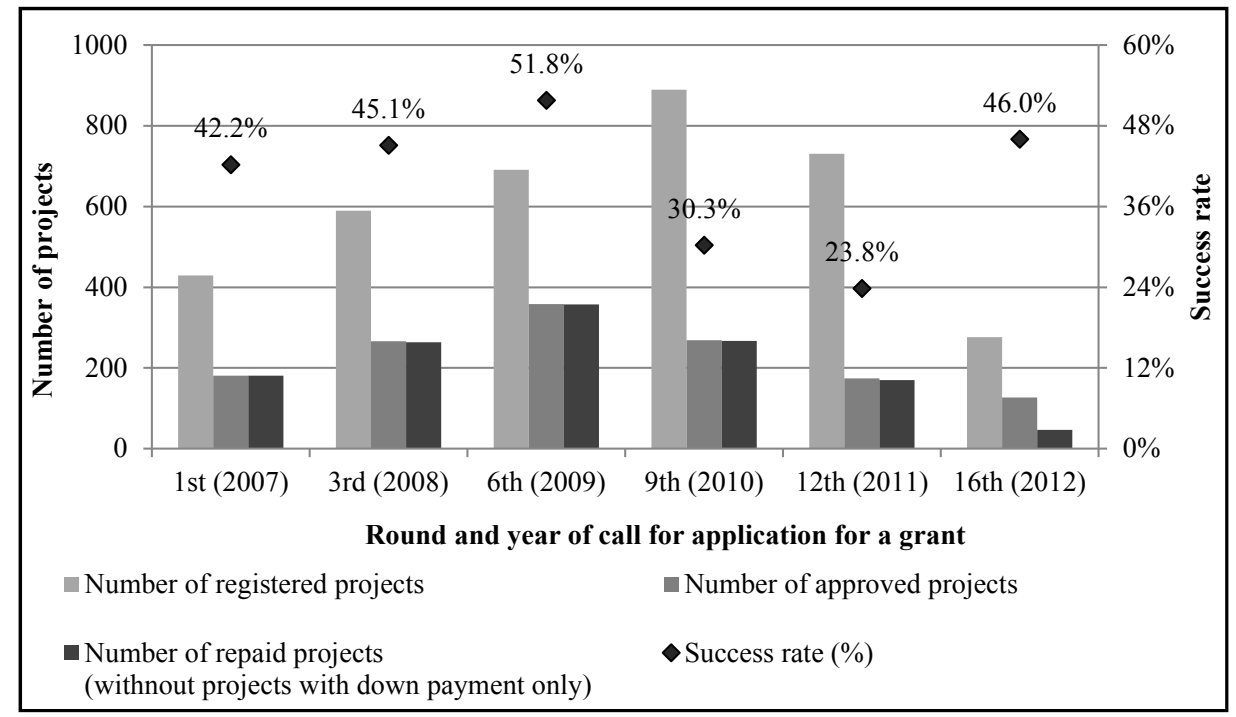

Source: Own display of data by MoA (2014b)

Figure 1: Projects supported from measure 1.3.2 Setting up of young farmers' businesses of the RDP 2017-2013. 
with a value over CZK 3.9 bil. registered, from which 1286 projects with a value of CZK 1.3 bil. were re-paid so far (as of 30th September 2014). Each farmer had on average CZK 1.1 mil. at his or her disposal. Success rate indicates the possibility for the farmers to obtain the subsidy when they apply for a grant.

For future planning of agricultural policy and support to young farmers, it is necessary for the Steering body of the RDP to know the number of young farmers in the future. In other words, the MoA should know the number of potential beneficiaries of the grants.

As the phenomenon of population ageing concerns all economic developed countries, "not only projections of the whole population, but often special projections of the development of the number and age structure of employees of various professions are computed (Fiala, Langhamrová, 2011). However, as far as the authors of the paper are concerned there has not been done a population projection of agricultural workers yet. Researches are only in other areas - e.g. Fiala, Langhamrová (2011) projected ICT experts, Fiala and Langhamrová (2012) the graduates of informatics field and Šimpach and Pechrová (2014) forecasted the population structures in predominantly rural regions in the Czech Republic.

The detailed analysis with policy implications is so far only mild. On the EU level, there could be mentioned a research of Zawojska (2011) who assessed the age imbalances between EU agriculture workers. She founded the disparity between the age of managers (and agriculture holders) and ordinary workers in agriculture in 27 member states of the European Union. However, her research divides the farmers only into 3 age groups (young, middle-aged and old) and lacks detailed segmentation. The author mainly analyses the possibilities of European policy to change significant disparities between the agricultural managers and ordinary agricultural workers. Despite that Czech Agrocensus surveys observe farmers according to the age groups; the categorization does not match the age borders used for policy formulation (i.e. young farmer under 40 years of age, and "old" farmer over 55 years). The Agrocensus utilizes classification to agricultural workers until 34 years, 35 to 54 years, and over 55 years. However, EU uses division to young (under 40 years) and other farmers. We also consider category of farmers over 55 years as old as this population was eligible for support from RDP measure 1.3.3 Early retirement. The projections calculated in this paper are also adjusted to the policy formulation framework - i.e. consider 7 years intervals of the EU's financial framework. The focus on policy formulation needs is one of the contributions of this paper.

The aim of the paper is to project the age-and-sex structure of agricultural workers and especially young farmers and to discuss the policy implications of the development. The structure of the paper is as follows. Firstly we present utilized data and their sources, and methods used to project the population of agricultural workers. In the next section the results of two population projections are introduced. The implications for agricultural policy are discussed next. Last section summarizes the findings and concludes.

\section{Materials and methods}

In the following subsections we present used data and their resources, then the assumptions of the models and their resources, and finally the projections.

\section{Used data}

The most accurate initial values of agespecific number of economically active farmers in the Czech Republic comes from the complete results of the Census 2011, organized by Czech Statistical Office (CZSO). We utilize them in our paper. There is available the age-and-sex structure of the population of the Czech Republic and of economically active farmers in 5-year age groups from 15-19 to 70+ completed years of life. The projections are done until 2041 in order to follow EU's financial frameworks and programme periods: 2014-2020, 2021-2027, 20282034, and 2035-2041. Our results are compared to Agrocensus - a specialized survey on farm structure and on agricultural production methods conducted by CZSO in particular years.

\section{Assumptions of the models}

Firstly, the assumptions regarding the migration and calculations of the life expectancy, fertility and mortality of the projections are introduced. Then the progress of projections of the population of the Czech Republic is described. Finally we introduce the way of projection of the agricultural workers and of the young farmers (owners or managers of the agricultural holdings).

Population projections of the economically active farmers in the Czech Republic are calculated 
on the basis of own population projections of the total population of the Czech Republic. Estimates of future age-and-sex specific population structure of economically active farmers are calculated using the cohort-component method on the basis of two probable scenarios (denoted model A and model B).

Because there were 132245 economically active persons working in agriculture in 2011 only, this group is enough small that the migration balance can be neglected (or we can assume that a difference of immigrants and emigrants is equal to zero).

Regarding the life expectancy in the Czech Republic, several researches (e.g. Fiala, Langhamrová (2011), Šimpach, Langhamrová, (2012) or Šimpach, Pechrová (2013)) proved, that the standard of living, health, social welfare and other factors affect the length of human life, and thus increase the life expectancy of the population of the Czech Republic. CZSO uses when calculating the population projections three scenarios: low (pessimistic), medium (baseline) and high (optimistic) variant. Medium variant seems to be the most probable expert estimation of life expectancy of 0 -year-old persons. It assumes a gradual increase in life expectancy at birth from 74.75 years in 2011 to 81.68 in 2041 for males and 80.82 years in 2011 to 86.93 in 2041 for females (see Figure 2 - left). Both models calculated in this paper, model A and model $\mathrm{B}$, works with expert judgment of evolution of life expectancy at birth according to the CZSO's medium variant. Nevertheless, the variant of life expectancy estimate used in this population projection is also associated with medium variant of the total fertility rate estimate of Czech females. However, the total fertility rate is too high and seems unlikely based on recent studies (see e.g. Šimpach, 2015).

Therefore, we utilized estimates of age-specific fertility rates and the overall total fertility rate which were elaborated by Šimpach (2015) - see his model "LC (Lee-Carter) 1988-2012" based on a highly sophisticated modelling method elaborated by authors Ronald Lee and Lawrence Carter (see Lee, Carter, 1992). The LC model 1988-2012 uses principal components of fertility in the years from 1988 to 2012, and therefore reflects the latest changes in the thoughts of fertility in the Czech society (the trend of having lower number of children, postponing the childbirth to the higher age (30 years and over) etc.). CZSO's low variant expertly judge the a slight increase of the total fertility rate from 1.48 live births in 2011 to 1.55 live births in 2041 per 1 female during her reproductive period. Pessimistic variant of LC model 1988-2012 from paper of Šimpach (2015) assumes gradual decline from 1.43 live births in 2011 to 1.38 live births in 2041. These estimates are shown in Figure 2 (right).

The model A works with the expected development of the total fertility rate of Czech females by CZSO's expert judgment in low variant, model $B$ utilizes the expected total fertility rate from Šimpach (2015).

3. Cohort-component method of population projection

Cohort-component method is based on the assumption that the person at the exact age $x$ years and in calendar year $t$ will be exactly one year older in the followed year with a certain probability (Stauffer, 2002). For the calculation we need to know the current population by age and sex (in one-year or shorter five-year age intervals), the mortality scenario and expected fertility trend.

The algorithm which is not completely universal is specifically derived for this paper. We use complete life tables for males and females in the Czech Republic in 2011, which shows the calculated mortality scenario in the form of table number

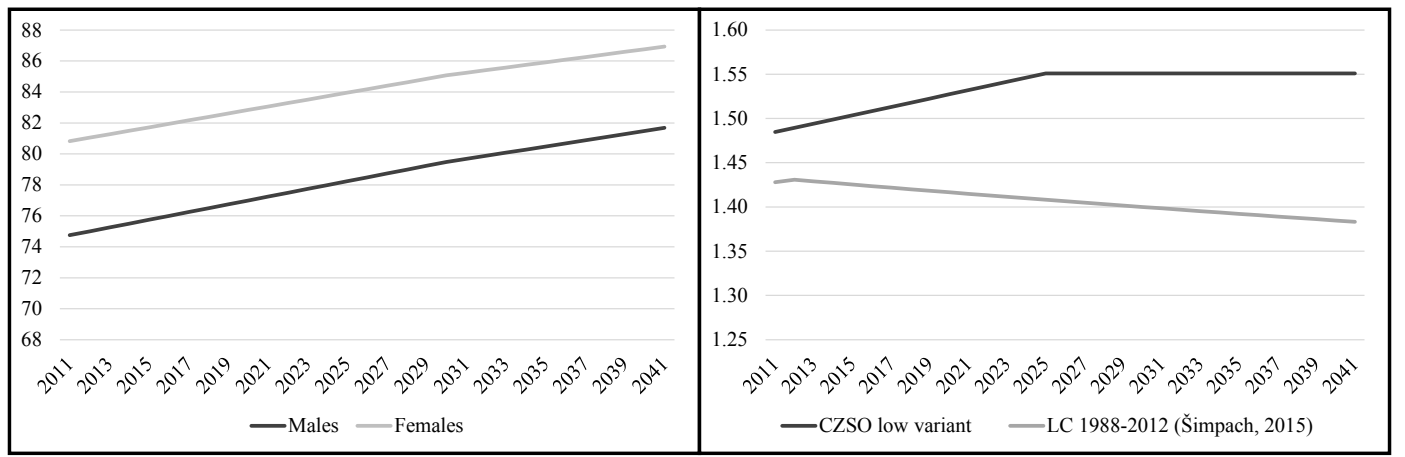

Source: own elaboration

Figure 2: Life expectancy at birth in 2017-2013 (left) and total fertility rate of Czech females in 2017-2013 (right). 
of surviving males and females $l_{x, t=2011}$, where $\mathrm{x}=0,1, \ldots, 105$ are completed years of life. The table with numbers of surviving males and females in the years 2012-2041 are not yet known, but can be estimated based on the aggregate indicator of predicted life expectancy at birth (see e.g. Dotlačilová et al., 2014). Let us denote

est $e_{0, t}=\frac{\sum_{x=0}^{105} l_{x, t}-\frac{l_{0, t}}{2}}{l_{0, t}}$,

where $e_{0, t}$ is the life expectancy at birth of the person in year $t, l_{x, t}$ is the table number of surviving persons x-year-old in year $t$. "Radix" (the root) of the mortality tables is normally set on value of 100000 persons. We calculate the other values $l_{x, t=2012-2041}$ together with the estimated coefficient of decrease of the probability of the death. In order to apply a simple equations (2) and expression (3) to estimate the further table number of surviving these coefficients must be set to value of 0.979 for males and 0.977 for females. The auxiliary calculations are as follows:

est $e_{0, t}=e_{0, t}^{C Z S O}$,

where $e_{0, t}{ }^{C Z S O}$ are expert estimates of life expectancy at birth of males and females according to the CZSO in Fig. 2 (left),

$l_{x+1, t+1}=l_{x, t+1} \times\left[1-\frac{i x^{q} \times\left(l_{x, t}-l_{x+1, t}\right)}{l_{x, t}}\right]$,

where $i x^{q}$ is the coefficient of decrease of the probability of death of males or females respectively.

Number of live born persons by age of mother in 2011 is known $\left(N_{x, t=2011}\right)$, as well as the mid-year number of females in $2011\left(S_{x, t=2011}\right)$. Age-specific fertility rates of Czech females can be expressed as

$f_{x, t}=\frac{N_{x, t}}{S_{x, t}}$,

where $x=15-49$ completed years of life. The total fertility rate is simply sum of all agespecific fertility rates in a given year $t$ (see equation 5).

$$
t f r_{t}=\sum_{x=15}^{49} f_{x, t}
$$

Model A, which is based on expert estimates of the total fertility rate according to $\mathrm{CZSO}$, must assume the unchanged distribution of age-specific fertility rates up to the year 2041. (Moreover this assumption is followed by the CZSO itself in its own projections). The distribution for age range from 15 to 49 completed years of life from 2011 is obtained as

$i x_{x, t=2011}^{f}=\frac{f_{x, t=2011}}{t f r_{t=2011}}$,

We use the expert estimates of $t f r_{t}$ by CZSO for the period 2012-2041 displayed in the Figure 2 (right). The development of age-specific fertility rates of Czech females is extrapolated as

$f_{x, t=2012-2041}^{\text {Model A }}=t f r_{t=2012-2041}^{C Z S O} \times i x_{x, t=2011}^{f}$.

For model B we utilize the age-specific fertility rate by Šmpach (2015). The results will be more precise.

Projection coefficients represent the probability with what x-year-old person will be exactly one year older after one year. In the case of live-born persons it is a quotient of infant mortality. Projection coefficient for born persons is denoted as $P_{*, t}$ and is true that

$P_{*, t}=\frac{L_{0, t}}{l_{0, t}}$

where radix of mortality tables $l_{0, t}=100000$ and $L_{0, t}$ is the table number of spent years of 0 -yearold persons. Because these numbers are unknown, we have to estimate them. From the algorithm of mortality tables is derived following relation

$L_{0, t}=l_{0, t}-\left(\alpha \times d_{0, t}\right)$,

where $\alpha$ is the ratio of lower elementary file of death, (CZSO commonly use $\alpha=0.85$ ), and $d_{0, t}$ is the table number of 0 -year-old deaths. This number is also unknown and must be estimated. The algorithm of mortality tables is

$d_{0, t}=l_{0, t} \times q_{0, t}$,

where $q_{0, t}$ is the probability of death of 0 -year-old persons - i.e. the probability that 0 -year-old person dies before reaches his/her first birthday. This probability is expressed based on the probability calculus as the supplement to 1.0. The probability of death is equal to

$q_{0, t}=1-\left(\frac{l_{1, t}}{l_{0, t}}\right)$.

Substituting the unknown into the formula (10), 
and then into (9) we obtain

$$
L_{0, t}=l_{0, t}-\left\{\alpha \times\left[l_{0, t} \times\left(1-\left(\frac{l_{1, t}}{l_{0, t}}\right)\right)\right]\right\} \text {. }
$$

Projection coefficient for $\mathrm{x}$-year-old person is expressed as

$$
P_{x, t}=\frac{L_{x+1, t}}{L_{x, t}} \text {. }
$$

Any other tables with numbers of spent years of life, which are unknown, are estimated by the formula

$$
L_{x, t}=\frac{\left(l_{x, t}+l_{x+1, t}\right)}{2} \text {. }
$$

The procedure is further fully managed by the cohort-component method. The number of inhabitants aged $x+1$ at time $t+1$ is estimated up to the year 2041 as

$$
S_{x+1, t+1}=S_{x, t} \times P_{x, t} \text {. }
$$

Projection tables begin to be empty over time from the top as they are not any live-born children known. These numbers must be estimated as

$$
N_{t}=\sum_{x=15}^{49} \frac{S_{x, t}^{\text {females }}+S_{x, t+1}^{\text {females }}}{2} \times f_{x, t},
$$

while from the known proportion of boys and girls at birth is separately calculated as

$$
N_{t}^{\text {Males }}=0,515 \times N_{t} \text { and } N_{t}^{\text {Females }}=0,485 \times N_{t} \text {. }
$$

Empty space in the projection tables is consequently completed by

$$
S_{0, t+1}=N_{t} \times P_{*, t},
$$

which resulting in a complete population projections of the population of the Czech Republic until 2041 based on the model A and model B. This projection is in 1-year age intervals, which must be converted to 5-year intervals for consistency with the data of economically active workers in agriculture.

It is supposed that the share of agricultural farmers on the total population will not change. This assumption is reasonable as "work in agriculture is not for majority of young people too attractive or perspective, average salaries in a sector are long-term under the Czech Republic's average" (CZSO). However, the proportions of young, middle-aged and old agricultural workers do change.

Similar approach was also taken for example by Fiala and Langhamrová (2012) when they assumed that since 2010 the number of students enrolled for bachelor's studies of informatics fields each year will be stable and equal to $11.2 \%$ of people at the age of 19 years.

Therefore, the proportion of the number of farmers in the relevant age group on the total number of persons in the population is expressed as

$i x_{x, t}^{a g}=\frac{S_{x, t}^{a g}}{S_{x, t}^{\text {population }}}$,

where $x=15-19 \ldots 70+$ respectively $x=15-19 \ldots$ 70-74. The last age interval of the economically active farmers is opened, but due to the fact that the frequency in this age group is quite small, we do not make a big mistake when we consider the interval $70+$ as comparable to a closed interval 70-74. Moreover, this measure is commonly used e.g. by Šimpach and Pechrová (2013). Estimation for future years is made by using the formula

$S_{x, t+1}^{a g}=S_{x, t+1}^{\text {population }} \times i x_{x, t}^{a g}$

up to the year $t=2041$.

\section{Implications for young farmers}

For the MoA it is necessary to know the number of potential eligible recipients of the subsidies from operation supporting young farmers. Therefore, it needs to know not only the share and the number of young agricultural workers, but also the number of farmers who are managers or owners of agricultural holdings. They are not specifically observed by CZSO. We utilize two approaches to estimate how many of the young agricultural workers actually are owners or managers. It is an approximate method as the eligible recipients are the beginners in their business and might not be captured in the statistics in Census 2011 (CZSO, 2011). The number of managers or owners was observed together with lawmakers for each age group during this Census.

There were 5992 of managers in agriculture, forestry and fishery as of 26th March 2011 which accounts for $4.5 \%$ of the total workers. The share of managers younger than 40 years was $25.8 \%$. The share of young owners or managers on the total number of employees was $1.2 \%$. For the purpose of estimation we utilize the share of young managers in the category of young agricultural workers which was $3.5 \%$. Hence, for example as in 2011 there were 44424 of agricultural workers under 40 years, $1545(3.5 \%)$ of them were managers. We assume the share to stay stable. In other words, the situation where the policy measures stay the same as they were set in the future is modelled. 


\section{Results and discussion}

\section{Results}

Following chapter give results of the models A and B. Both calculated population projections suggest that the number of agricultural workers will decrease with the decrease of the total number of population in the Czech Republic. While there were 132245 agricultural workers in 2011, the model A shows that there will be 108069 or 106771 based on model B in 2041. The difference in projections is due to the supposed total fertility rate. CZSO is rather optimistic and project increase of total fertility rate. Contrary to that, the model B constructed by Šimpach (2015) projects the decrease of total fertility rate. While total fertility rate was 1.43 in 2011, CZSO set total fertility rate on 1.55 in 2041, and model B predicted the total fertility rate to be 1.38 in 2041. While CZSO considers the fertility rate to increase on average by $0.25 \%$ annually, the growth rate of total fertility rate is $0.10 \%$ in model $\mathrm{B}$ meaning that total fertility rate decreased on average by $0.10 \%$ annually. The differences in projections between models are the same throughout the whole article and therefore are not discussed further.

Despite the increase in fertility rate in CZSO model, the population of agricultural workers will decrease. It is due to the population development of the Czech Republic, aging and longevity (see e.g. study by Dotlačilová and Šimpach, 2015). Population structure of the Czech Republic becomes regressive as it is typical for Western European countries with all issues that this change brings.

Regarding the proportion between males and females, it is possible to conclude that it will not change rapidly. In 2011, the females accounted for $30.1 \%$ of the agricultural workers, while in 2041 it was only $28.7 \%$ (according to both models). This is in line with current development trends. CZSO (2012) reported that the share of females on total regularly employed workers in agriculture did not change too much between 2000 and 2010 - it decreased by 1.0 percentage point (p.p.).

While the proportion of the agricultural workers on the total population is assumed to stay constant overtime, the age structure of the agricultural workers will undergo significant changes. The development in the period 2011 to 2041 is displayed at Fig 2. The share of young farmers under 40 years of age will decrease from 33.6\% in 2011 to $26.7 \%$ in 2041 (according to model A) or even to $25.8 \%$ (model B). According to CZSO model the age category $55+$ is the only one where the number of agricultural workers will increase (by 1 197). Otherwise there is a decrease expected in category 40 to 54 years (by 9754 workers) and in young farmers' category (15 to 39 years, by 15690 ). Model B does not differ in higher age categories, but only in the first one (due to different assumed fertility rate). It predicts that the number of young agricultural workers will decrease even by 16916 workers. This is in line with current trends noted by CZSO. According to the Agrocensus surveys, "the share of young productive generation (i.e. to 34 years) on the total number of regularly employed between 2000 and 2010 decreased from $22.9 \%$ to $20.1 \%$ " (CZSO, 2012).

As it can be seen from the Figure 3 the age structure of agricultural workers will change within observed period of time. According to the model A the share of young farmers will decrease and be the lowest in years 2032 to 2034 (2034 in case of model B). Then the share will start to slightly grow. Nevertheless, the maximal share of the young farmers already had been in 2011 and 2012 (according to the both models). On the other hand, the number of middle aged agricultural workers will grow until 2026/2027 and will continually decrease since that. The share of old farmers will start to grow since 2018 and will peak in years 2036-2038 (at 32.3\% level according

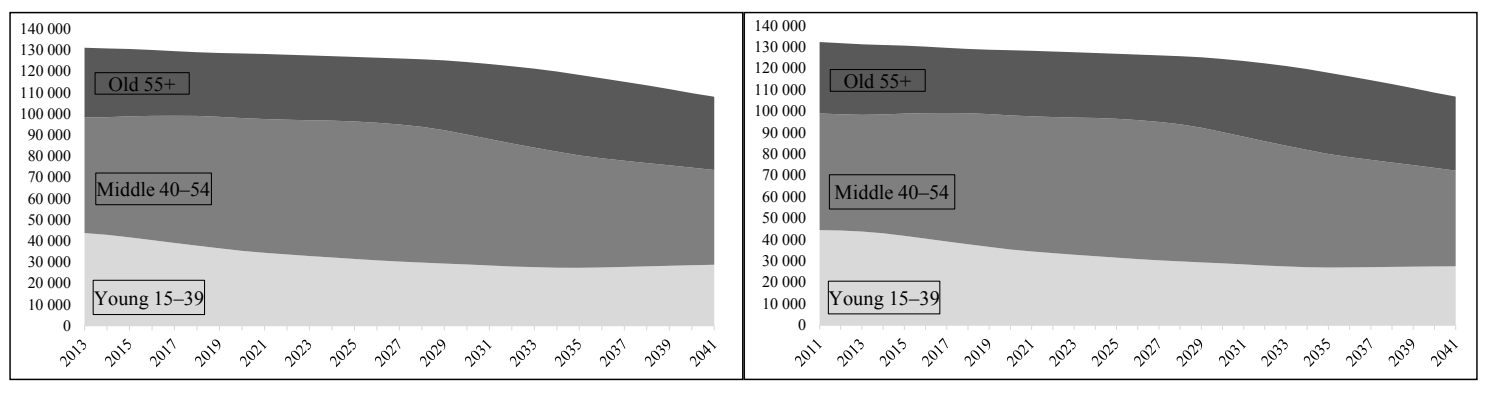

Source: own elaboration

Figure 3: Number of agricultural workers according to the age categories in 2011-2041 (model A - left, model B - right). 
to model A) or 2038 (at $32.6 \%$ level according to model B).

There can be differences observed in the age categories within the same gender group. In the category of young workers, the share of females was lower $(31.5 \%)$ than the share of males $(34.5 \%)$ in 2011 . There were also more males in category of old agricultural workers $(27.0 \%)$ than females $(21.2 \%)$. On the other hand the share of females in middle age category was higher $(47.3 \%)$ than the share of males $(38.5 \%)$. The projection displayed in population pyramid at Figure 4 shows how the age-and-sex structure of agricultural workers will develop in the future. The projections are given in 7-year intervals in order to follow the financial framework of the EU.

According to the model A, the share of young males in the total population of male agricultural workers will firstly decrease, but later it will start to grow again. It is due to the fact that the second generation of so-called Husák's children ${ }^{1}$ will have children (i.e. children which were born recently will enter the reproduction period). The lowest share of young males in agriculture is expected in years 2033 and 2034 (23.3\%). The highest share of males already had been in year 2011. On the other hand, the share of middle aged workers will increase until 2026. Consequently it will decrease till the end of the projected period. The share of old male workers will be in minimum in 2018 (25.4\%), but

\footnotetext{
1 Between 70s and early 80s of the last century the former Czechoslovakia was under political and economic influence of communist regime. At this time, the government of President Gustav Husák decided to significantly support families with more children using birth allowance and material benefits (strollers, household equipment etc.) Generation that arises after this political population interference is often called "Husák's children", or "Strong generation of $70 \mathrm{~s}$ ".
}

will grow since that until 2038 where the share will reach $35.2 \%$ ).

The projection of model B differs slightly in later predicted years. The highest share of young farmers is similar (in 2011), but the lowest is in year 2034 (23.1\% only - which is more pessimistic than according to the model A). On the other hand the category of male middle aged farmers was the lowest at the beginning (2011, $38.5 \%$ ) and is increasing since that until 2026(48.4\%) when it will start to decrease again. The only category which share will grow during almost all projection period (until 2038) are the old male workers in agriculture. The highest share will be $35.5 \%$ as the lowest was at the beginning (2018, $25.4 \%$ ). The share of middle age farmers is and still will be the highest, but the share of young farmers will be higher than old farmers only until 2024. Then the shares will switch (see Figure 5 left).

The development of the shares of different age categories in female group will be analogical to male group, but the share of young females will stay higher than the share of old for longer time than in male group (see Figure 5 - right). According to the model $\mathrm{A}$, the lowest share of females in the young category will be the lowest $(21.6 \%)$ between years 2032 and 2034. It was the highest in $2012(31.6 \%)$. Middle aged group is always the most frequent, the share of females in this category will rise until 2026, 2027 up to 58.2\% and then it will decrease again. But it will never be as low as it was in $2011(47.3 \%)$. The share of old females will increase almost continuously and will peak at $25.6 \%$ in 2035, 2036. The lowest share of old females will be already in 2018. Model B gave similar results regarding the years of minimal and maximal shares of each age category at the total number of female agricultural workers.

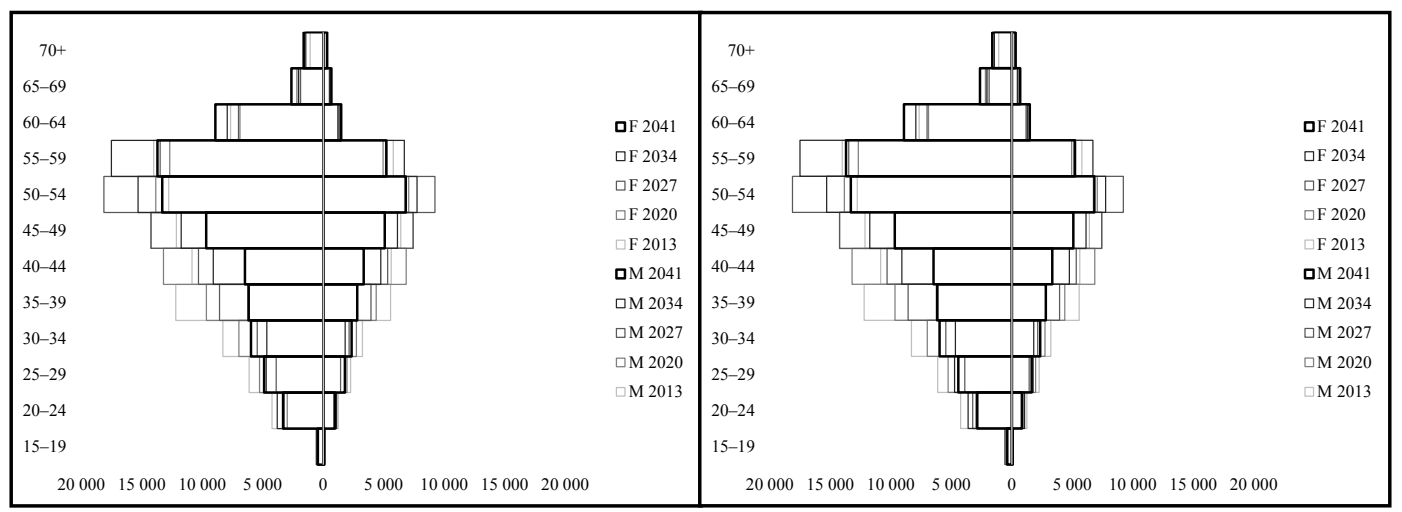

Source: own elaboration

Figure 4: Projection of age-and-sex population structures of agricultural workers in 2013-2041 by 7year intervals (actual on $1^{\text {st }}$ January, model A - left, model B - right). 


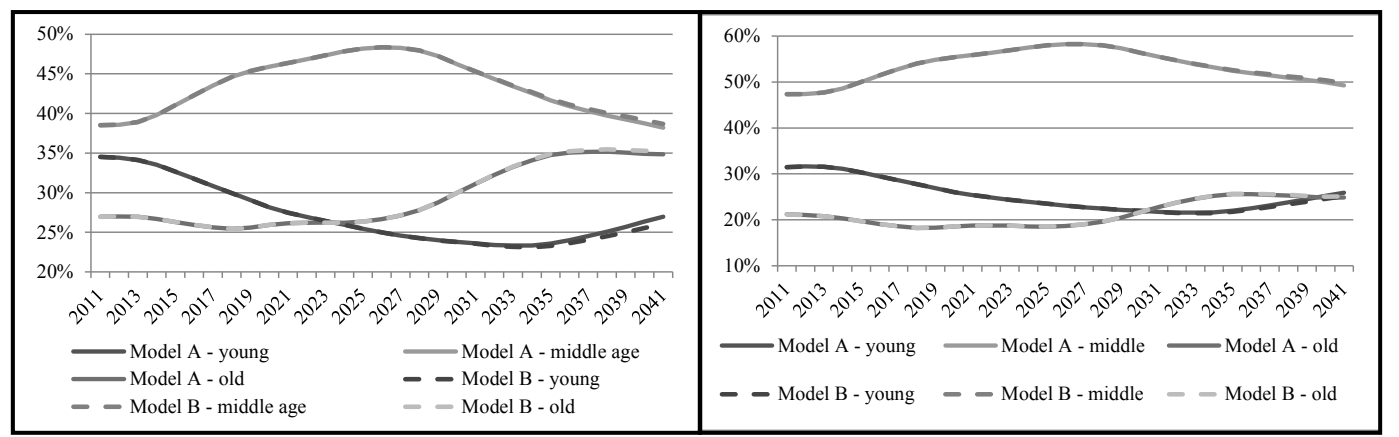

Source: own elaboration

Figure 5: Development of the shares of young, middle aged and old agricultural workers in 2011-2041 (males - left, females - right).

\section{Discussion}

For the steering body of the RDP (i.e. for the MoA) it is necessary to know the number of potential eligible recipients of the subsidies from particular measures. The number of managers or owners was observed together with lawmakers for each age group in Census 2011. The share of young managers in the category of young agricultural workers was $3.5 \%$ which is supposed to be stable overtime. For example in 2011, there were 44424 of agricultural workers under 40 years from which 1545 were managers. The number of young managers or owners will decrease as same as the number of agricultural workers in total. At the end of the projected period, there will be only 723 male and 279 female or 688 male and 268 female farms' managers according to the model $\mathrm{A}$ and $\mathrm{B}$ respectively. Figure 6 shows the development from 2011 until 2041 separately for males and females. In order to provide the decision makers with needed data for creation of the RDP, similar data are provided also in tabular form (see Table 1 in Appendix which displays particular number of young farmers projected for one year before the start of the programme period).

The change of the number of young farmers has implications to the subsidies' policy formulation. The RDP measure 1.3.2 Setting up of young farmers businesses implemented in 2007-2013 supported 1471 young farmers with 1484 projects in total. In 2011, 187 farms' owners or managers obtained subsidies in nominal value of CZK 1.1 mil. Each farmer obtained the subsidy for 5 years to implement his or her business plan. According to the projections in this paper, there were 1545 owners or managers less than 40 years old in 2011; therefore, around $12.1 \%$ of the total number of young farmers was supported. The share was $9.1 \%$ one year later when 140 young farmers out of 1538 received finances for setting of their business. Of course that not all supported farmers were already captured by the statistics as they started their business for the first time. In the next RDP for years 2014-2020 it is set that the farmers can run agricultural production for maximum 36 months. Besides the eligible applicant has to comply with the definition of small or micro business and achieve at least the minimal value of standard production (expressed in CZK per annual working unit).

Our population projections suppose no change to the policy conditions as they are difficult to predict. With above stated limitations, we may consider several future scenarios of development of the support for the young farmers. Also some organizations calculate own population projections dealing with questions how many people and farmers will be on the Earth and who will feed the planet. For example Jöhr (2012) considers the situation in 2030 and raise the question how the world will be able to feed 8.2 bil. people who will live on Earth according to OECD at that time. Study done by Zawojska (2011) answered some of these questions, but considered the past development only (until 2010). There is no vision of how the situation in 27 European Union member states might evolve in the future (for example until 2030, or as in our study, until 2041).

Since 2026, the share of the young farmers will be the lowest of all. There were 1538 young farms' managers or owners in 2013, but only 1002 (according to model A) or 957 (according to model B) of them in 2034. The total amount of given financial aid to one owner or manager of agricultural holding will remain the same (CZK 1.1 mil.) for this purpose. We calculated the financial envelope for particular year needed in order to support certain percentage of farmers. The share of supported farmers will have to change 

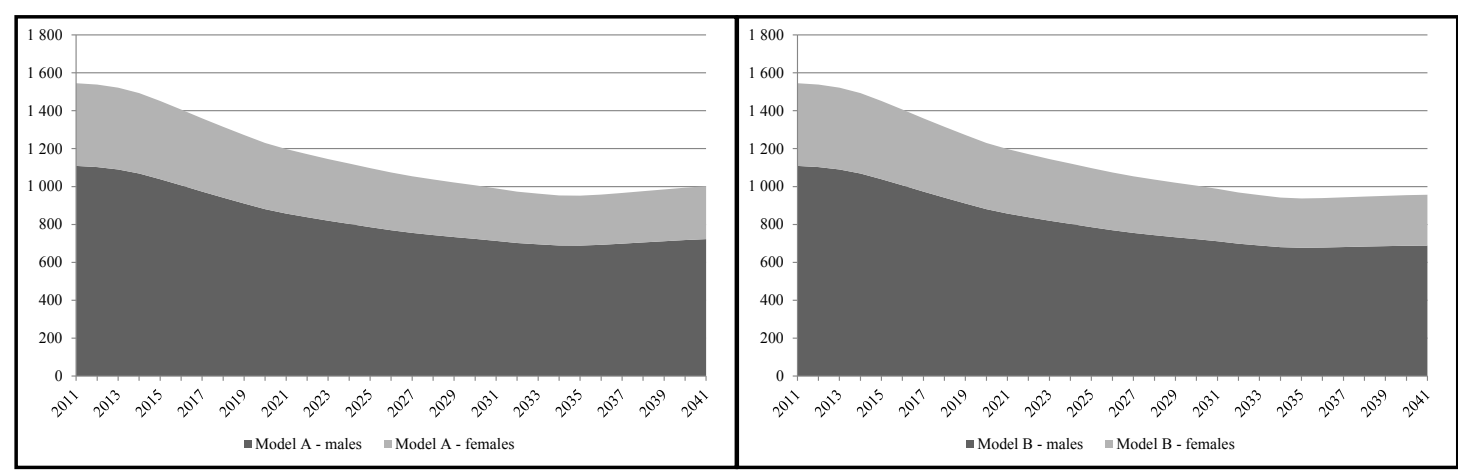

Source: own elaboration

Figure 6: Development of the number of the young farmers (owners or managers of agricultural holdings) - model A (left), model B (right).
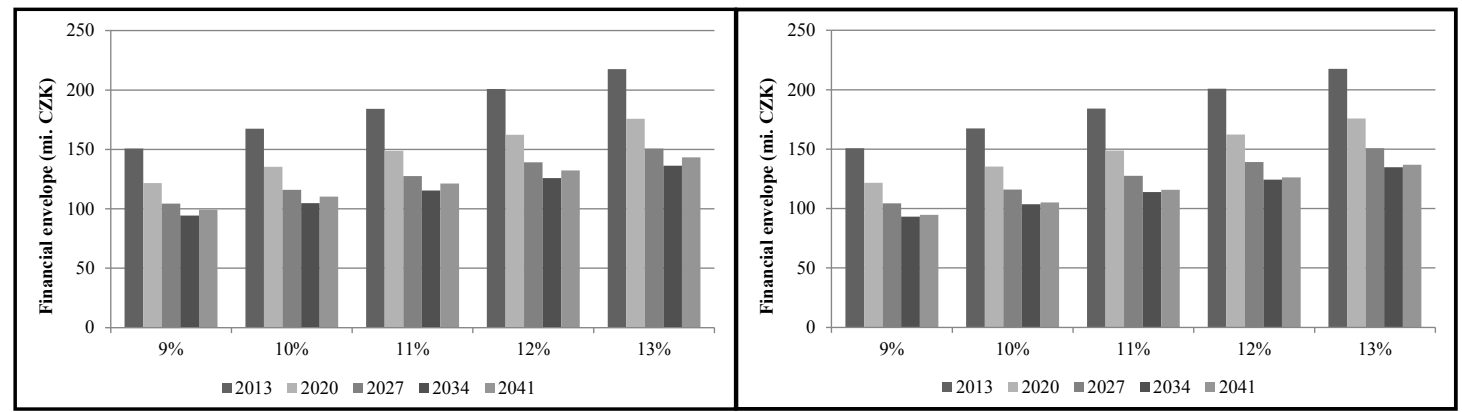

Source: own elaboration

Figure 7: Financial envelope needed for next programme period to financially support certain share of young owners or managers of agricultural holdings (model $\mathrm{A}$ - left, model B - right).

each year as some of them would be already supported in previous years and would not be able to benefit from the subsidies again. There might be also more newcomers to the sector which are not included in the projections. The models assume that the percentage share of agricultural workers on the total population will be the same as in 2011 . The simulations are displayed at Figure 7.

It is obvious that with decreasing number of young farmers, there will be less need for support. While in 2011 there were $12.1 \%$ of farm managers supported by CZK 205.7 bil., in 2020 would be less money (CZK 162.3 bil.) needed to cover $12.0 \%$ of young farmers and managers population. In 2027, the same amount as in 2011 will be sufficient even for more than $17.6 \%, 2034$ for more than $19.5 \%$ of young managers or owners. However, the number of young farmers will grow within the programme period of 2035-2041. Hence, in 2041 would the same amount as in 2011 covered only $18.6 \%$ of the potential recipients of the support for young farmers.

We must also take into account that public finances devoted to the operation are limited.
For the financial framework 2014-2020 it is planned to achieve total public spending in height of EUR 30 mil. on the priority $2 B$ facilitate the entry of sufficiently qualified farmers into the agricultural sector, and in particular the generational renewal in this sector i.e. on measure 6.1.1 Setting up of young farmers' business (MoA, 2014a). Therefore, the total number of supported young farmers will be dependant also on disposable public finances.

\section{Conclusion}

The aim of the paper was to project the age-andsex structure of agricultural workers until 2041 and to model possible scenarios of the development of subsidies from the European Union's funds which support the entry of the young people to the sector. Despite that Agrocensus surveys observe farmers according to the age groups the categorization does not match the age borders used for policy formulation. Our article uses division to young (under 40 years), middle aged ( 40 to 55) and old (over 55) farmers. The projections were also calculated until 2041 in order to follow 
the programme period of the EU.

A cohort-component method and data from Census 2011 were used for population projection. There were two variants calculated: model A worked with the expertly judged development of the total fertility rate of Czech females in the low variant and model B utilized values calculated by Šimpach (2015). The number of agricultural workers was derived based on their share on the total population in 2011. Similarly the number of young farms' owners or managers was drawn from their share on the total number of young farmers in 2011.

The share of young agricultural workers (both males and females) on the number of total agricultural workers will change within the projected period. The number of agricultural workers over 55 years will continuously grow and of the young under 40 years will decrease until 2026 when the number of old will exceed the young. In the same year, the share of middle aged workers will be the highest. The number of young farms' owners or managers of farms will decrease until 2035. After this year it will start to grow as the second generation of so-called Husák's children will enter the reproduction period.

The change of the number of young farmers has implications to the subsidies' policy formulation. It will be possible (and also necessary in order to improve age-and-sex structure) to support more applicants. While in 2011 it there were $12.1 \%$ of young farmers (potential applicants for subsidies) and $23.8 \%$ of the real applicants supported by EUR 205.7 bil., this amount will be able to cover $18.6 \%$ of young applicants in 2041. However, the models do not account for completely new entrants into the agricultural sector. They assume that the percentage share of agricultural workers on the total population will be the same as in 2011 throughout the whole projected period. Therefore, the challenge for future research is to examine this aspect - possibly by modelling and projecting of the number of graduates from agricultural high schools or universities with relevant field of studies.

\section{Acknowledgements}

Authors gratefully acknowledge Czech Science Foundation project No. P402/12/G097 DYME - "Dynamic Models in Economics" and the long term institutional support of the Faculty of Informatics and Statistics, University of Economics Prague for supporting this paper.

Corresponding author:

Ing. Ondřej Šimpach

Faculty of Informatics and Statistics University of Economics Prague,

W. Churchill sq. 4, 13067 Prague 3 - Žižkov, the Czech Republic

Phone: +420 224095 273, Mobile phone:+420 7376654 61,E-mail: ondrej.simpach@vse.cz

\section{References}

[1] Alexopoulos, G., Koutsourisa, A. Tzouramani, I. Should I stay or should I go? Factors affecting farmers' decision to convert to organic farming as well as to abandon it. IFSA: Proceedings of the $9^{\text {th }}$ European IFSA Symposium. 2010, p. 1083-1093. [Online]. Available: http://ifsa.boku.ac.at/ cms/fileadmin/Proceeding2010/2010_WS2.3_Alexopouos.pdf [Accessed: 29 Jul 2014].

[2] Czech Statistical Office (CZSO). Pracovní síly v zemědělství, Czech Statistical Office, 2012. [Online]. Available: http://www.czso.cz/csu/2012edicniplan.nsf/t/62002E535B/\$File/ 212712k11. pdf [Accessed: 1 Mar 2015].

[3] Davis, J., Caskie, P., Wallace, M. Economics of farmer early retirement policy. Applied Economics. 2009, Vol. 41, No. 1, p. 35-43. ISSN 0003-6846.

[4] Davis, J, Caskie, P., Wallace, M. Promoting structural adjustment in agriculture: The economics of New Entrant Schemes for farmers. Food Policy. 2013, Vol. 40, p. 90-96. ISSN 0306-9192.

[5] Dotlačilová, P., Šimpach, O., Langhamrová, J. DERAS Versus MS EXCEL Solver in Levelling the Life Expectancy at Birth. 13th Conference on Applied Mathematics - Aplimat 2014. 2014, p. 108-114. ISBN 978-80-227-4140-8.

[6] Dotlačilová, P., Šimpach, O. Polynomial functions and smoothing of mortality rates: The Czech 
Republic and Slovakia during their independent development after their separation. 14th Conference on Applied Mathematics - Aplimat 2015. 2015, p. 221-231. ISBN 978-80-227-4314-3.

[7] Fiala, T., Langhamrová, J. ICT experts in the Czech Republic - development in the past and future prospects. Proceedings of the $19^{\text {th }}$ IDIMT Conference (Interdisciplinary Information Management Talks). 2011, p. 51-58.

[8] Fiala, T., Langhamrová, J. The Expected Development of the Graduates of Informatics Field. Proceedings of the $20^{\text {th }}$ IDIMT Conference (Interdisciplinary Information Management Talks). 2012, p. 257 - 358. ISBN 978-3-99033-022-7.

[9] Galanopoulos, K., Abas, Z. Laga, V., Hatziminaoglou, I., Boyazogluc, J. The technical efficiency of transhumance sheep and goat farms and the effect of EU subsidies: Do small farms benefit more than large farms? Small Ruminant Research. 2011, Vol. 100, p. 1-7. ISSN 0921-4488.

[10] Jöhr, H. Where are the Future Farmers to Grow Our Food? International Food and Agribusiness Management Review. 2012, Vol. 15, Iss. A (special issue), p. 9-11.

[11] Lee, R.D., Carter, L.R. Modelling and forecasting U.S. mortality. Journal of the American Statistical Association. 1992, vol. 87, p. 659-675.

[12] Ministry of Agriculture (MoA). Program rozvoje venkova na období 2014-2020, Ministry of Agriculture, 2014a. [Online]. Available: http://eagri.cz/public/web/file/321101/PRV_do_vlady.pdf [Accessed: 12 Mar. 2015].

[13] Ministry of Agriculture (MoA). 17. zasedání MV PRV 18. 11. 2014, Ministry of Agriculture, 2014b. [Online]. Available: http://eagri.cz/public/web/mze/dotace/program-rozvoje-venkovana-obdobi-2007/monitorovaci-vybor/podklady-z-jednani/x17-zasedani-mv-prv-18-11-2014.html [Accessed: 12 Mar. 2015].

[14] Polain, J. D., Berry, H. L., Hoskin, J. O. Rapid change, climate adversity and the next 'big dry': Older farmers' mental health. Australian Journal of Rural Health. 2011, Vol. 19, No. 5, p. 239-243. ISSN 1038-5282, E.ISSN 1440-1584,

[15] Stauffer, D. Simple tools for forecasts of population ageing in developed countries based on extrapolations of human mortality, fertility and migration. Experimental Gerontology. 2002, Vol. 37, No. 8-9, p. 1131-1136. ISSN 0531-5565.

[16] Šimpach, O. Fertility of Czech Females Could Be Lower than Expected: Trends in Future Development of Age-specific Fertility Rates up to the Year 2050. Statistika. 2015, Vol. 95, No. 1, (in press). ISSN 1804-8765.

[17] Šimpach, O., Langhamrová, J. Czech Household Computer Facilities as a Reliable Variable in a Life Expectancy Forecast Model up to the Year 2060. Proceedings of the $20^{\text {th }}$ IDIMT Conference (Interdisciplinary Information Management Talks). 2012, p. 143-152. ISBN 978-3-99033-022-7.

[18] Šimpach, O., Pechrová, M. Assessing the impact of standard of living on the life expectancy at birth using Vector Autoregressive Model. Proceedings of Mathematical Methods in Economics 2013. 2013, p. 921-926.

[19] Šimpach, O., Pechrová, M. The Impact of Population Development on the Sustainability of the Rural Regions. Agrarian perspectives XXIII. - The Community-led Rural Development, 2014, p. 129-136. ISBN 978-80-213-2545-6.

[20] Zawojska, A. Policy Challenges in Reducing Age Imbalances in the EU Agriculture. Economic Science for Rural Development: Resources and education, [Book series]. 2011, Iss. 25, p. 144-152. 


\section{Appendix}

\begin{tabular}{|c|c|c|c|c|c|c|c|}
\hline Year & $\begin{array}{c}\text { Decision-making } \\
\text { for programme period }\end{array}$ & \multicolumn{3}{|c|}{ Model A } & \multicolumn{3}{c|}{ Model B } \\
\hline & & Total & Males & Females & Total & Males & Females \\
\hline 2013 & $2014-2020$ & 6563 & 4701 & 1861 & 6563 & 4701 & 1861 \\
\hline 2020 & $2021-2027$ & 5304 & 3798 & 1506 & 5304 & 3798 & 1506 \\
\hline 2027 & $2028-2034$ & 4546 & 3258 & 1288 & 4545 & 3257 & 1288 \\
\hline 2034 & $2035-2041$ & 4110 & 2972 & 1138 & 4062 & 2934 & 1128 \\
\hline 2041 & $2042-2048$ & 4321 & 3117 & 1204 & 4126 & 2969 & 1157 \\
\hline
\end{tabular}

Source: own elaboration

Table 1: The number of young owners or managers of agricultural holdings a year before new programme period. 